Ege Tıp Dergisi / Ege Journal of Medicine 2015; 54: Ek Sayı / Supplement 46-50

\title{
Sarkopeniden korunma
}

\section{Prevention of sarcopenia}

\author{
Sumru Savaş
}

Ege Üniversitesi Tıp Fakültesi, İç Hastalıkları Anabilim Dalı, Geriatri Bilim Dalı, İzmir

\section{Öz}

Sarkopeni için yapılmış çeşitli tanımlamalar mevcuttur. Bunlardan "Avrupa Yaşlılarda Sarkopeni Çalışma Grubu"(EWGSOP) sarkopeniyi "fiziksel engellilik, düşük hayat kalitesi ve ölüm gibi istenmeyen sonuçların riskini taşıyan, iskelet kas kütlesinin ve gücünün ilerleyici ve jeneralize kaybı ile karakterize bir sendrom" olarak tanımlamıştır. Ayrıca sarkopeni tanısı için "düşük kas kütlesi + düşük kas fonksiyonu (güç veya performans)" kullanımını önermektedir. İntrensek (yaşa bağı) nedenlerin yanında çeşitli ekstrensek ve davranışsal faktörler de sarkopeni gelişimi ve/veya ilerlemesini etkiler. Bu faktörler arasında kullanmama, fiziksel aktivite eksikliği, malnütrisyon, kronik enflamasyon ve komorbiditeler sayılabilir ve sürece katkıları kişiden kişiye büyük farklılık gösterebilir. Bu yüzden bireyler arasında kas kütle ve gücü kaybı açısından ciddi varyasyonlar mevcuttur. Koruyucu stratejiler; primer, sekonder, tersiyer ve kuvaterner seviyede tanımlanır. Mevcut bilgimize göre tüm koruma seviyelerinde fiziksel egzersiz ve nütrisyon en önemli elementlerdir. Primer koruma, altta yatan sürecin başlangıcı ile başlamalıdır. Sekonder ve tersiyer koruma stratejileri daha ilerideki yaşlarda sarkopeninin hızlı ilerlemesinden kaçınmak için düşünülmelidir.

Anahtar Sözcükler: Korunma, kuvaterner, primer, sarkopeni, sekonder, tersiyer.

\section{Abstract}

There are several definitions for sarcopenia. European Working Group on Sarcopenia in Older People (EWGSOP) defines sarcopenia as "a syndrome characterized by progressive and generalized loss of skeletal muscle mass and strength with a risk of adverse outcomes such as physical disability, poor quality of life and death. Additionally, the presence of both low muscle mass + low muscle function (strength or performance) is also recommended as a parameter for the diagnosis of sarcopenia. Intrinsic, multipl extrinsic and behavioral factors (i.e. disuse, physical activity, malnutrition, chronic inflammation and comorbidities) affect the development and/or progression of sarcopenia. There may be interindividual variabilites in the contribution of these factors to the course of the disease. Preventive strategies include primary, secondary, tertiary and quaternary levels. According to the present knowledge, physical exercise and nutrition are the most important elements in all preventive levels. Primary prevention should begin as soon as the underlying process starts. Secondary and tertiary prevention strategies take place in older ages to avoid rapid progression of sarcopenia.

Keywords: Prevention, quaternary, primary, sarcopenia, secondary, tertiary.

\section{Sarkopeni Tanımı ve Tarihçesi}

Sarkopeni, geriatri ve gerontolojide oldukça sık kullanılan bir terim olmasına, bireysel ve toplumsal önemli maliyetlere neden olmasına rağmen son zamanlara kadar araştırmalarda ve klinik pratikte kullanılabilecek ve tüm dünyada yaygın olarak kabul edilmiş olan bir sarkopeni tanımı bulunmuyordu $(1,2)$. Gözlenen klinik tabloya ilk olarak 1988'de Rosenberg "sarkopeni" terimini önermiştir (3). Sarkopeni prevalansını araştırmaya yönelik ilk epidemiyolojik çalışmalar kas kütlesinin biyoelektrik empedans veya dansitometre ile ölçülmesine dayandırılmıştır.

\section{Yazışma Adresi: Sumru SAVAŞ}

Ege Üniversitesi Tıp Fakültesi, İç Hastalıkları Anabilim Dalı, Geriatri Bilim Dalı, 35100 Bornova, IZMiR
Örneğin Baumgartner, dansitometre ile appendiküler iskelet kas kütle ölçümünün boya göre düzeltilmesine dayanan bir tanım kullanmış ve sarkopeniyi; "referans seks spesifik sağlıklı genç popülasyona (18-40 yaş) göre iki standart deviasyon daha düşük olma" olarak tanımlamıştır $(1,4)$. Ancak kas kütlesi, kas fonksiyonu, fiziksel performans ve diğer sonuçlar arasındaki ilişki lineer değildir $(1,5,6)$. Bu yüzden sadece kas kütle ölçümünün bazı pratik sınırlılıkları mevcuttur (1). 2001'de Morley, sarkopeniyi "ilerleyen yaş ile meydana gelen iskelet kas kütle ve güç kaybı" olarak tanımlamıştır (7).

Son zamanlarda, sarkopeniyi daha iyi anlamak için bazı uluslararası fikir birliği tanımları yayınlanmıştır (8-10). Örneğin, yaş-ilişkili sarkopeni için, Uluslararası Sarkopeni Çalışma Grubu [International Working Group 
on Sarcopenia (IWGS)] ortak bir görüş ile "iskelet kas kütle ve fonksiyonunun yaş ilişkili kaybı" şeklinde tanım yapmıştır. Daha sonra bu grup sarkopeniyi "tüm vücut veya appendiküler yağsız kütle düşüklüğü ve kötü fiziksel fonksiyon kombinasyonu" şeklinde tanımlamıştır (10).Yine yaş ilişkili sarkopeni için; klinik pratiğe uygun tanım ve fikir birliği sonucu oluşturulan tanı kriteri 2010 yılında "Avrupa Yaşılıarda Sarkopeni Çalışma Grubu" [European Working Group on Sarcopenia in Older People (EWGSOP)] tarafından geliştirilerek rapor edilmiştir (8). EWGSOP, sarkopeniyi "fiziksel engellilik, düşük hayat kalitesi ve ölüm gibi ters sonuçlar riskini taşıyan, iskelet kas kütlesinin ve gücünün ilerleyici ve jeneralize kaybı ile karakterize bir sendrom" olarak tanımlamıştır. Sarkopeni tanısı için ise; kas kütlesi ve kas fonksiyon düşüklüğünün (düşük güç ve/veya düşük fiziksel performans) tespit edilmesi önerilmektedir $(2,8)$. 2013'te Asya ve Amerika'dan uluslararası uzmanlar ile EWGSOP ve IWGS temsilcileri bir araya gelerek Uluslararası Sarkopeni Girişimi'ni [International Sarcopenia Initiative (ISI)] oluşturmuşlardır. Bu grup da sarkopeni üzerine çalışmalarına devam etmektedir (2).

\section{Sarkopeni Prevalansı}

Sarkopeni prevalansı, kullanılan metoda bağlı olarak değişkenlik göstermektedir (11). Daha yaşlı kohortlarda prevalans hem kadın hem erkeklerde artmaktadır. Ancak belli spesifik bir yaş grubundaki kişilerin sarkopeni kriterlerini tam olarak karşılamasalar da, hem kalitatif hem de kantitatif olarak kas kaybına uğramış oldukları düşünülebilir. Bu kişiler ve sarkopeni tanısı almış kişiler de daha önceki zamanlarda ve halen de patofizyolojik mekanizmalara maruz kalmaktadırlar. Sonunda herkesin kullanılacak tanı kriterine bağlı olarak bir dereceye kadar sarkopenik olup olmayacağı tartışmaya açık bir konudur (1). Uluslararası Sarkopeni Girişimi'nin 50 yaş ve üzeri popülasyonlarda yapılmış sarkopeni çalışmalarını değerlendirdiği sistematik derlemede sarkopeninin ("düşük kas kütlesi ve düşük kas fonksiyonu ve/veya düşük fiziksel performans" olarak tanımlandığında) toplumda yaşayan bireylerde en az 20 kişiden birinde görüldüğü ve huzurevlerinde yaşayan kırılgan yaşıılarda prevalansın 3 kişide 1 gibi yüksek oranlara ulaştığı belirtilmiştir. Bu çalışma ile sonuç olarak, bölgesel ve yaşa bağlı varyasyonlarla ilişkili olarak toplumdaki sarkopeni prevalansı \%1-29 arasında, uzun dönem bakım popülasyonlarında \%14-33 ve hastane bazlı akut bakım popülasyonunda \%10 olarak belirtilmiştir (2).

\section{Sarkopeni Önlenebilir mi?}

Insanlarda fizyolojik sistemlerin çoğu yaşlanma ile 30 ile 70 yaş arasında, yılda ortalama \%0.34-1.28 oranında geriler. Bu yüzden sarkopeninin, yaşlanmanın kaslar üzerine etkisi sonucu oluştuğu düşünülebilir. İntrensek (yaş ilişkili) nedenlerin yanında çeşitli ekstrensek ve davranışsal faktörler de sarkopeni gelişimi ve/veya ilerlemesini etkiler. Bu faktörler arasında; kullanmama, fiziksel aktivite eksikliği, malnütrisyon, kronik enflamasyon ve komorbiditeler gibi etkenler sayılabilir; bu faktörlerin sürece katkıları kişiden kişiye büyük farklılık gösterebilir. Bu yüzden bireyler arasında kas kütle ve gücü kaybı açısından ciddi varyasyonlar mevcuttur. Sarkopeni hem bir süreç hem de sonuçtur (1). Bu yüzden konuyla ilgili süreçler bu bakış açısı ile değerlendirilmelidir.

Toplumda yaşayan yaşlılarda potansiyel olarak değiştirilebilir yaşam tarzı faktörlerinin (fiziksel aktivite, gıda alımı, güneşe maruziyet) ve kronik hastalıklar ile ilaç kullanımının sarkopeni üzerine etkisini, genel olarak epidemiyolojik araştırma literatürünü gözden geçirerek araştıran bir derlemede; fiziksel aktivite, gıda alımı ve güneşe maruziyetin yaşla azaldığı, yaşlılarda kas kütlesinin korunması ve fonksiyonel düşüşlerin önlenmesi açısından değişen fakat önemli faydalarının olabileceği, ancak yaşla artan kronik hastalıklar ve ilaç kullanımlarının sarkopeni ilerlemesini artırabileceği belirtilmiştir. Genel fiziksel aktivite seviyelerinin ise özellikle arzu edilen vücut kompozisyonunun sürdürülmesi ile sarkopeniden korunmada faydalı olabileceği ve bu ilişki için bir eşik noktasının bulunmadığı rapor edilmiştir (12).

Son zamanlardaki çalışmalardan elde edilen veriler sonucunda; hızlı velosite direnç egzersizlerinin yaşlılarda kas kuvveti ve fonksiyonel kapasite açısından etkili tedaviler olabileceği, aerobik egzersiz eğitiminin ise; mitokondriyal biyoenerjetikleri iyileştirme, insülin duyarlılığını düzeltme ve/veya oksidatif stresi azaltma yoluyla yaşlanan iskelet kasına faydalı olabileceği düşünülmektedir (13).

\section{Sarkopeniden Korunma}

Sarkopeniden koruyucu stratejiler; primer, sekonder, tersiyer ve kuaterner seviyede tanımlanır (Tablo-1). Tedavi ve korunma birbirinden ayrı yaklaşımlardır, ancak sarkopeni için girişimler bu iki durumda benzer patofizyolojik süreçleri hedef almaktadır. Mevcut bilgimize göre tüm koruma seviyelerinde fiziksel egzersiz ve nütrisyon en önemli elementlerdir. Farklılık, kişinin desteklenmesi ve yönlendirilmesi noktasında belirginleşir. Primer ve sekonder korunmada vaka tayini için düşük yürüme hızı seviyeleri uygun değildir, bu seviyede çoktan tersiyer koruma veya tedavi endikasyonu mevcuttur. Fonksiyonel engellilik klinik bulguları olmayan kişiler için kas performans değerlendirmesi uygun olabilir. El sıkma gücü ölçümü kolaydır ve yaş ilişkili değişiklikler diğer kas gruplarındaki güç kayıpları ile paralel gider $(14,15)$.

Dördüncül koruma; kanıta dayalı olmayan tedavi veya girişimlere karşı hastaların uyarılmasını kapsamaktadır (1). Henüz sarkopeniden korunmak için farmakolojik tedavi olarak yayınlanmış bir kanıt bulunmamaktadır (16). Tüm korunma seviyelerinde dördüncül koruma önerileri paralel gitmelidir (1). 
Protein alımının yaşla nispi olarak ters ilişkili olduğu belirtilmiştir (1). Günde 1,2 gr/kg düzeyinden fazla protein alanlarda hastalık riski daha az bulunmuştur (17). Randomize kontrollü çalışmalarda, tek büyük bolus yerine her öğünde yeterli yüksek kalitede protein (25-30 gr) alımının önemli olduğu belirtilmiştir (18). PaddonJones ve Rasmussen yaşlanmanın yüksek kaliteli protein alımına anabolik cevabı kaçınıımaz olarak azaltmadığını; bu cevabı azaltan patofizyolojinin daha çok karbonhidrat varlığında insülin direncinin protein sentezine etkileri yoluyla gerçekleştiğini belirtmektedirler. (19). Bu veriler, yüksek kaliteli proteinlerin küçük miktarlarda ve karbonhidratlar olmadan alınması gerektiğini göstermektedir (1). Ayrıca düşük gıda alımı da sarkopeni gelişimi ve ilerlemesi için önemli bir risk faktörüdür (20).

Cruz-Jentoft ve arkadaşlarının 2014'de yaptığı sistematik derlemede; egzersiz girişimlerinin kas gücü ve fiziksel performansı orta kanıt seviyesinde düzelttiği, beslenme ile ilgili çalışmaların heterojen ve yetersiz sayıda olduğu, $2.5 \mathrm{gr}$ lösin ve $\beta$-hidroksi $\beta$-metilbütirik asiti içeren esansiyel amino asit eklerinin kas kütle ve fonksiyon parametreleri üzerine bazı etkilerinin bulunduğu, ancak protein eklerinin kas kütle ve fonksiyonu üzerine tutarlı etkilerinin görülmediği belirtilmiştir (2).

Yaşlı bireyler Vitamin D eksikliği açısından risk altındadırlar ve düşük vitamin $D$ seviyelerine sahip yaşlı bireylerde sarkopeni ile mücadelede fonksiyonel düşüşlerin engellenmesi ve düşme riskinin azaltılması için vitamin D tedavisi önerilebilir (21).

a. Primer koruma: Hastalık ve engellilik oluşmadan alınacak önlemlerdir. Sarkopeni bir geriatrik sendromdur, bu yüzden iyi tanımlanmış hastalıklara göre sarkopeniden korunma, sağlıklı davranış değişiklikleri gerektirdiği için çok daha büyük bir mücadele yapılmalıdır. Sarkopeni için bu sağlıklı davranış değişiklikleri; iyi beslenme ve hijyen ile yeterli egzersiz ve dinlenme gibi genellikle kültürel olarak etkilenen ve derin kökleri olan, sağlıklı yaşam tarzının temel aktivitelerini içerir.
Primer koruma, genç erişkin yaşta, altta yatan sürecin başlangıcı ile başlamalıdır (1). Sarkopeniyi anlama ve yönetiminde yaşam boyu yaklaşım şekli yeni ve ilginç bir alandır (22).

Tablo-1. Hastanın Durumuna ve Hekimin Değerlendirmesine Göre Sarkopeniden Korunma Seviyesi (1).

\begin{tabular}{c|c|l|l}
\hline \multicolumn{2}{c|}{} & \multicolumn{2}{c}{ Doktor (Belirtiler) } \\
\cline { 3 - 4 } & & $(-)$ & $(+)$ \\
\hline Hasta & $(-)$ & Primer & Sekonder \\
\cline { 3 - 4 } (Semptomlar) & $(+)$ & Dördüncül & Tersiyer \\
\hline
\end{tabular}

Bu yaklaşıma göre, daha geç yaşlardaki kas kütle ve fonksiyonu sadece kas kayıp oranını değil, aynı zamanda erken yaşlarda edinilmiş tepe noktasını da yansıtır (Şekil-1)(23). Bu yüzden iskelet kas kaybı kadar, doğum kilosu ve erken nütrisyon gibi kas kütle ve gücü tepe noktası ile ilişkili faktörler ile bu ilişkilerin altında yatan mekanizmalar da dikkate alınmalıdır (22, 24-26).

Klinik bir yaklaşımla, primer koruma; el sıkma gücü normal beklenen değerlerde olan tüm yetişkinleri kapsar. Kişiler sağlıklı yaşam davranış şekilleri hakkında bilgilendirilmeli ve farkındalıkları arttırılmalıdır.

Tüm erişkinlerin her gün en az 30 dakika orta dereceli fiziksel aktiviteyi içeren, aktif bir yaşam tarzı yaşamaları önerilmelidir. Doz-cevap ilişkisi göz önüne alındığında, büyük kas gruplarını uyaran ve ortalamanın üzerindeki şiddette fiziksel egzersiz haftada 2-3 kez önerilebilir. Bu egzersiz spesifik egzersiz gruplarında olabileceği gibi eksternal rehberlik olmadan da yapılabilir (1). Yaşlılarda fiziksel aktivite önerilirken ayrıca kişinin korkuları, kişisel tercihleri, sosyal desteği, çevresel engeller de göz önüne alınmalıdır (27).

Beslenme açısından primer korunmada; dengeli Akdeniz tipi diyet, günde çeşitli öğünlere bölüştürülmüş yüksek kaliteli protein (1.0-1.2 gr/kg) ve 400-1000 iü vitamin D (uygun vakalarda 800-2000 ï̈) tedavisi önerilmektedir (1).

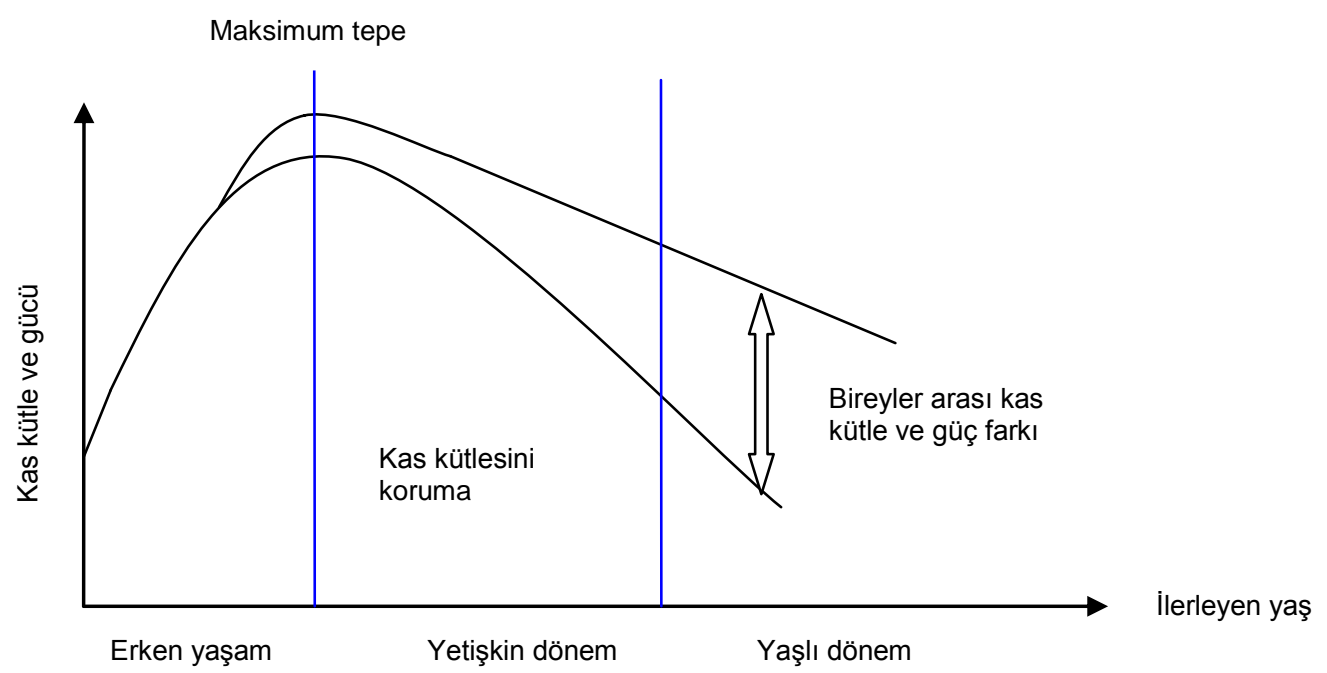

Şekil-1. Sarkopeniye yaşam boyu yaklaşım (23 numaralı kaynaktan değiştirilerek alınmıştır). 
b. Sekonder koruma: Sekonder korumada amaç, hastalık veya bir durumu, belirgin semptomlar ortaya çıkmadan, başarılı bir şekilde tedavi edilebileceği erken evrede tespit etmektir. Sekonder korumada normal değerlerden düşük, ancak tanımlanmış kesme noktalarının üzerinde el sıkma gücü olan ve sarkopeniye bağlı fonksiyonel engelliliği olmayanlar hedef alınır. Bu kişilerdeki egzersiz önerileri, normal kas performansı olan kişilerle benzerdir. Komorbiditeler, ilaç kullanımına bağlı olarak komplikasyonlar açısından artmış risk söz konusu olduğunda daha yüksek seviyede egzersiz süpervizyonu düşünülebilir (adapte egzersiz sınıfları veya fizyoterapist gözetiminde egzersiz gibi).

Beslenme açısından sekonder korunmada; diyet hikayesinin alınması ve diyetisyen önerilerinin uygulanması, kişiselleştirilmiş Akdeniz tipi diyet, günde çeşitli öğünlere bölüştürülmüş yüksek kaliteli protein (1.0-1.2 $\mathrm{gr} / \mathrm{kg}$ ) ve 800-2000 ï̈ vitamin D tedavisi önerilmektedir (1).

c. Tersiyer koruma: Tersiyer koruma programları, halihazırda sınırlayıcı komplikasyonlar ve engellilikler şeklinde bir hastalık veya durumdan etkilenmiş olan kişilerin hayat kalitesini düzeltmeyi, durumun ciddiyetini ve ilerleyişini azaltmayı, ve fonksiyonellik ile öz yeterliliği restore etmek üzere rehabilitasyon sağlamayı hedefler. Daha önce de belirtildiği gibi, düşük yürüme hızı seviyelerinde tersiyer koruma veya tedavi endikasyonu mevcuttur (1). EWGSOP, vaka tespiti için yürüme hızında $0.8 \mathrm{~m} / \mathrm{sn}$ kesme noktasını önermektedir (8). IWGS ise yürüme hızında kesme noktası $<1 \mathrm{~m} / \mathrm{sn}$ olduğunda sarkopeni tanısı koymak için vücut kompozisyonunun değerlendirmesini önermektedir (10). Bu aşamada sarkopeni değerlendirmesi ve multidisipliner yaklaşım önerilmektedir.

Tersiyer korunmada beslenme açısından; diyet hikayesinin alınması ve diyetisyen önerilerinin uygulanması, kişiselleştirilmiş Akdeniz tipi diyet, günde çeşitli öğünlere bölüştürülmüş yüksek kaliteli protein $(1.2-1.5 \mathrm{gr} / \mathrm{kg})$ ve 800-2000 ï̈ vitamin D tedavisi önerilmektedir. Uygun vakalarda ise; ayrıca esansiyel aminoasitler ve lösin içeren beslenme ilavelerinin verilmesi de önerilmektedir (1).

\section{Kaynaklar}

1. Vandewoude M, Bautmans I. Sarcopenia: Is it preventable? In: Cruz-Jentoft AJ, Morley JE (eds.). Sarcopenia. Wiley-Blackwell. 2012; 392-407.

2. Cruz-Jentoft AJ, Landi F, Schneider SM, et al. Prevalence of and interventions for sarcopenia in ageing adults: a systematic review. Report of the International Sarcopenia Initiative (EWGSOP and IWGS). Age Ageing 2014;43(6):748-59.

3. Rosenberg IH. Sarcopenia: origins and clinical relevance. J Nutr 1997;127:990S-1S.

4. Baumgartner RN, Koehler KM, Gallagher D, et al. Epidemiology of sarcopenia among the elderly in New Mexico. Am J Epidemiol 1998;147(8):755-63.

5. Goodpaster BH, Park SW, Harris TB, et al. The loss of skeletal muscle strength, mass, and quality in older adults: the health, aging and body composition study. J Gerontol A Biol Sci Med Sci 2006;61(10):1059-64.

6. Janssen I, Baumgartner RN, Ross R, Rosenberg IH, Roubenoff R. Skeletal muscle cutpoints associated with elevated physical disability risk in older men and women. Am J Epidemiol 2004;159(4):413-21.

7. Morley JE, Baumgartner RN, Roubenoff R, Mayer J, Nair KS. Sarcopenia. J Lab Clin Med 2001;137(4):231-43.

8. Cruz-Jentoft AJ, Baeyens JP, Bauer JM, et al. Sarcopenia: European consensus on definition and diagnosis: Report of the European Working Group on Sarcopenia in Older People.Age Ageing 2010;39(4):412-23.

9. Morley JE, Abbatecola AM, Argiles JM, et al. Society on Sarcopenia, Cachexia and Wasting Disorders Trialist Workshop. Sarcopenia with limited mobility: an international consensus. J Am Med Dir Assoc 2011;12(6):403-9.

10. Fielding RA, Vellas B, Evans WJ, et al. Sarcopenia: an undiagnosed condition in older adults. Current consensus definition: prevalence, etiology, and consequences. International working group on sarcopenia. J Am Med Dir Assoc 2011;12(4):249-56.

11. Bautmans I, Van Puyvelde K, Mets T. Sarcopenia and functional decline: pathophysiology, prevention and therapy. Acta Clin Belg 2009;64(4):303-16.

12. Scott $D$, Blizzard L, Fell J, Jones G. The epidemiology of sarcopenia in community living older adults: what role does lifestyle play? J Cachexia Sarcopenia Muscle 2011;2(3):125-34.

13. Forbes SC, Little JP, Candow DG. Exercise and nutritional interventions for improving aging muscle health. Endocrine 2012;42(1):29-38.

14. Merkies IS, Schmitz PI, Samijn JP, et al. Assessing grip strength in healthy individuals and patients with immune-mediated polyneuropathies. Muscle Nerve 2000;23(9):1393-401.

15. Lauretani F, Russo CR, Bandinelli $S$, et al. Age-associated changes in skeletal muscles and their effect on mobility: an operational diagnosis of sarcopenia. J Appl Physiol (1985) 2003;95(5):1851-60.

16. Visvanathan R, Chapman I. Preventing sarcopaenia in older people. Maturitas 2010;66(4):383-8.

17. Rousseta S, Patureau MP, Brandolinia M, Martina JF, Boiriea Y. Daily protein intakes and eating patterns in young and elderly French. Br J Nut 2003;90:1107-15.

18. Symons TB,Sheffield-Moore M, Wolfe RR, Paddon-Jones D. A moderate serving of high-quality protein maximally stimulates skeletal muscle protein synthesis in young and elderly subjects. J Am Diet Assoc 2009;109(9):1582-6.

19. Paddon-Jones D, Rasmussen BB. Dietary protein recommendations and the prevention of sarcopenia. Curr Opin Clin Nutr Metab Care 2009;12;86-90.

20. Morley JE. Anorexia and weight loss in older persons. J Gerontol A Biol Sci Med Sci 2003;58:131-7. 
21. Dawson-Hughes B. Serum 25-hydroxyvitamin D and functional outcomes in the elderly. Am J Clin Nutr 2008;88:537S-40S.

22. Sayer AA, Robinson SM, Patel HP, et al. New horizons in the pathogenesis, diagnosis and management of sarcopenia. Age Ageing 2013;42(2):145-50.

23. Sayer AA, Syddall H, Martin H, et al. The developmental origins of sarcopenia. J Nutr Health Aging 2008;12(7):427-32.

24. Sayer AA, Syddall HE, Gilbody HJ, Dennison EM, Cooper C. Does sarcopenia originate in early life? Findings from the Hertfordshire cohort study. J Gerontol A Biol Sci Med Sci 2004;59(9):M930-4.

25. Robinson SM, Simmonds SJ, Jameson KA, et al. Hertfordshire Cohort Study Group. Muscle strength in older communitydwelling men is related to type of milk feeding in infancy. J Gerontol A Biol Sci Med Sci 2012;67(9):990-6.

26. Patel HP, Jameson KA, Syddall HE, et al. Developmental influences, muscle morphology, and sarcopenia in communitydwelling older men. J Gerontol A Biol Sci Med Sci 2012;67(1):82-7.

27. Baert V, Gorus E, Mets T, Geerts C, Bautmans I. Motivators and barriers for physical activity in the oldest old: A systematic review. Ageing Res Rev 2011;10(4):464-74. 